\title{
INOVASI TEKNOLOGI TEPAT GUNA UNTUK MENINGKATKAN PRODUKTIVITAS, NILAI TAMBAH DAN AKSES PASAR USAHA MIKRO DI UNIT PERMUKIMAN TRANSMIGRASI “KARANG CAHYO” KABUPATEN BENGKULU SELATAN
}

\author{
Soengkono, Slamet Widodo \\ Fakultas Ekonomi dan Bisnis Universitas Bengkulu \\ Kanang S. Hindarto \\ Fakultas Pertanian Universitas Bengkulu \\ Slamet Widodo \\ Fakultas Ekonomi dan Bisnis Universitas Bengkulu \\ Sigit Mujiharjo \\ Fakultas Pertanian Universitas Bengkulu
}

\begin{abstract}
ABSTRAK
Soengkono, Kanang S. Hindarto, Slamet Widodo, Sigit Mujiharjo; Tujuan utama dari penelitian adalah untuk mengetahui: (1) latar belakang faktor ekonomi transmigran, (2) potensi sumber daya alam, (3) sumber daya manusia potensi transmigran, (4) analisis lingkungan bisnis, (5 ) model pengembangan usaha mikro, (6) membangun kelompok usaha mikro, (7) model formulasi berbasis potensi sumber daya manusia dan alam dengan teknologi sederhana dan diterima, (8) praktek teknologi sederhana dan diterima, (9) praktek pemasaran, dan (10) pelatihan kecil/ manajemen bisnis mikro. Hasil penelitian ini mengidentifikasi bahwa: (1) masyarakat transmigran memiliki motivasi tinggi untuk tinggal di lokasi studi, (2) keinginan masyarakat transmigran untuk fasilitasi dalam pembangunan ekonomi untuk menghasilkan pendapatan, (3) semangat masyarakat transmigran untuk untuk mengikuti program penelitian yang dilakukan oleh peneliti, (4) telah membangun kelompok usaha kecil, (5) telah dieksekusi teknologi sederhana dan diterima uji coba, (6) telah melaksanakan pelatihan manajemen usaha kecil, (7) manajemen pemasaran. Secara umum model berbasis potensi sumber daya manusia dan alam dengan teknologi sederhana dan diterima telah meningkat menghasilkan pendapatan transmigran.
\end{abstract}

\begin{abstract}
Soengkono, Kanang S. Hindarto, Slamet Widodo, Sigit Mujiharjo; The objective of the first research is to know: (1) the background of economic factors of transmigrant, (2) the natural resources potency, (3) the human resources of transmigrant potency, (4) the analysis of business environment, (5) the model micro business development, (6) the build of micro business group, (7) the formulation model based on human and natural resource potency with simple and accepted technology, (8) the practice of simple and accepted technology, (9) the practice of marketing, and (10) the training of small/micro business management. The result of the research is identified that: (1) the transmigrant society have a high motivation to stay at location study, (2) the transmigrant society wish to facilitation in economic development to income generating, (3) the transmigrant society zeal for to follow research program conducted by researcher, (4) have been build of small business group, (5) have executed of simple and accepted technology test-drive, (6) have executed of training of small business management, (7) marketing management. In general the model based on human and natural resource potency with simple and accepted technology have been increase of income generating of transmigrant.
\end{abstract}

Key Word: Transmigrant, Micro Business Development, Simple and Accepted Techology, Productivity, Value Added, Market Access, and Incoming Generating 


\section{PENDAHULUAN}

Unit Permukiman Transmigrasi (UPT) "Karang Cahyo" Kecamatan Pino Raya, Kabupaten Bengkulu Selatan memiliki luas lahan 300 hektar yang diperuntukkan 300 KK terdiri dari 200 KK transmigran penduduk asal (TPA) dan 100 transmigran penduduk setempat (TPS). Hasil penelitian pendahuluan yang dilakukan oleh peneliti menemukan bahwa kehidupan ekonomi warga transmigran dari tahun ketahun tidak mengalami peningkatan yang berarti (baca: tetap miskin). Kondisi ini antara lain disebabkan kurangnya pembinaan yang berkelanjutan dari instansi terkait yang berdampak pada pemanfaatan potensi sumberdaya lahan atau jatah lahan yang tersedia tidak optimal. Faktor lain adalah letak permukiman relatif jauh dari pusat kota kabupaten dan tidak adanya akses teknologi dalam upaya pengembangan usaha pertanian, menjadikan permasalahan ekonomi warga transmigran berkepanjangan.Sementara itu usaha para transmigran masih bersifat konvensional (non profit oriented) dan belum bersifat ekonomi produktif (business oriented). Kondisi ini ditunjukkan pada pasca panen dengan pola petik jual.Dengan demikian produk dari hasil pertanian tersebut tidak memiliki nilai tambah dan ketahanan simpan produk sangat terbatas, sehingga ketergantungan dengan tengkulak sangat tinggi dan akses pasarpun menjadi sangat terbatas (pasar lokal).Sementara itu kelompok usaha bersama (KUB) hasil bentukan program transmigrasi yang seharusnya diharapkan memiliki kemampuan sebagi motor penggerak perekonomian lokal dan membantu pengembangan usaha, tidak berfungsi sebagaimana yang diharapkan. Kondisi ini menyebabkan permasalahan dan tekanan ekonomi para transmigran menjadi berkepanjangan dan tidak pernah ada upaya penyelesaian sampai tuntas.

Berdasarkan Laporan Akhir Dinas Tenaga Kerja dan Transmigrasi Provinsi Bengkulu (2009) dan hasil survey pendahuluan yang telah dilakukan oleh peneliti, maka lokasi penelitian dipilih di Unit Permukiman Transmigrasi (UPT) Karang Cahyo, Kecamatan Pino Raya Kabupaten Bengkulu Selatan. Sedangkan sebagai dasar pertimbangan lainadalah sebagai berikut:

a. Letak UPT Karang Cahyo relatif dekat dengan Ibukota Kabupaten, sehingga mudah dijangkau dalam pelaksanaan kegiatan penelitian, pendampingan, monitoring dan evaluasi maupun pembinaan lanjutan.

b. Kehidupan ekonomi masyarakat transmigran UPT Karang Cahyo masih tergolong miskin.Rata-rata pendapatan keluarga transmigran masih tergolong sangat rendah atau sebesar Rp. 700.000,00 sampai Rp. 800.000,00 per KK/bulan dengan jumlah tanggungan keluarga rata-rata 3 sampai 4 orang per KK,sementara bantuan jatah hidup (jadup) dari pemerintah sudah tidak tersedia lagi.

c. Tekanan ekonomi keluarga transmigran sangat membutuhkan percepatan kearifan solusi pemecahannya, karena atas dasar kondisi tersebut, memiliki potensi masyarakat melakukan perambahan hutan lindung yang terletak sebelah utara UPT Karang Cahyo.

d. Kurangnya perhatian, bantuan dan pembinaan dari stake holders (pihak-pihak terkait) secara berkelanjutan mengakibatkan pemanfaatan lahan tidak optimal dan adanya ketidakpastian dan ketidakstabilan ekonomi keluarga transmigran.

e. Minat dan partisipasi masyarakat dalam bekerjasama dalam upaya meningkatkan pendapatan keluarga dan keluar dari tekanan ekonomi sangat tinggi.

f. Potensi pengembangan usaha mikro untuk industri rumahtangga cukup banyak tersedia, seperti: pisang, ubi kayu, ubi jalar, nangka, kacang tanah, terung, cabe, pepaya dan bambu. Selama ini hasil pertanian tersebut masih diusahakan secara konvensional (non bisnis oriented) dan ada ketergantungan dengan tengkulak..

g. Tidak ada akses teknologi atau pemanfaataan teknologi tepat guna pada usaha mikro masyarakat transmigran yang selama ini dilakukan.

Program pemberdayaan ekonomi masyarakat transmigran dalam upaya pengentasan kemiskinan di UPT Karang Cahyo perlu secepatnya dicarikan solusi penyelesaiannya secara arif dan bijaksana mengingat kondisi ekonomi para transmigran saat ini masih jauh dari sejahtera (tetap miskin). Upaya-upaya pemberdayaan ekonomi berbasis pada potensi sumberdaya lokal dan berwawasanlingkungan perlu terus digali, dikaji dan ditemukenali, dalam kerangka 
meningkatkan pendapatan masyarakat transmigran agar dapat hidup lebih layak dan berkecukupan.Berkaitan dengan permasalahan tersebut, maka perlu adanya pengenalan dan penerapan jenis usaha ekonomi produktif berbasis potensi sumberdaya lokal melalui penerapan teknologi tepat guna terpadu, yakni teknologi sederhaha dan murah untuk pengolahan komoditas hasil pertanian yang banyak terdapat di lokasi penelitian. Inovasi teknologi tepat guna ini menjadi semakin penting dalam upaya meningkatkan produktivitas, nilai tambah dan akses pasar dari produk-produk olahan yang dihasilkan oleh para transmigran. Melalui kombinasi strategis teknologi tepat guna terpadu yang relatif murah dan mudah dilakukan ini,masyarakat transmigran, sehingga masyarakat transmigrantidak terbatas hanya menaman dan menjual komoditas tersebut dalam keadaan basah/mentah, tetapi warga transmigran mampu mengolah hasil panen mereka yang sebenarnya masih memiliki nilai ekonomi yang cukup tinggi untuk peningkatan pendapatan rumah-tangganya.

\section{TUJUAN PENELITIAN}

Penelitian ini secara umum memiliki tujuan meningkatkan pendapatan (income generating) transmigran, melalui pemberdayaan ekonomi kerakyatan berbasis potensi lokal.Sedangkan Tujuan Khusus adalah mengembangkan usaha mikro berbasis potensi sumberdaya ekonomi lokal, melalui penerapan teknologi tepat guna terpadu untuk meningkatkan produktivitas, nilai tambah dan akses pasar secara berkelanjutan. Tahap-tahap yang dilakukan Tahun ke I adalah: Tahap Persiapan: (1) Pengumpulan data sekunder dan analisis sementara potensi ESDA dan ESDM, penyusunan panduan wawancara, Koordinasi dan pengurusan legalitas penelitian. Tahap Lapangan, meliputi: Sosialisasi program, Identifikasi dan pemutakhiran data base berkaitan dengan faktor-faktor yang melatarbelakangi kehidupan dan kegiatan ekonomi masyarakat transmigran, analisis potensi ekonomi sumberdaya alam lokal, analisis potensi ekonomi sumberdaya manusia lokal, analisiskondisi lingkungan usaha lokal, analisis potensi pasar, merumuskan alternatif model berbasis potensi lokal, dan memetakan pelaksanaan program, pembentukan kelompok sasaran program, penentuan model yang adaptif, produktif, inovatif dan marketable, pelatihan klasikal manajemen usaha kecil dan manajemen pemasaran produk hasil olahan, penentuan lokasi strategis untuk praktek uji coba, persiapan uji coba, dan praktek uji coba, yaitu: praktek pengolahan hasil pertanian, praktek membuat kemasan produk hasil olahan, praktek pemasaran pada pasar lokal dan regional, evaluasi dan sintesa, dan Penyusunan Laporan Penelitian. Tahun ke II (lanjutan Tahun ke I) meliputi: pelatihan klasikal: budidaya tanaman pisang, budidaya tanaman ubikayu dan budidaya tanaman ubi jalar, penentuan dan pemanfaatan lahan untuk uji coba budidaya tanaman, praktik budidaya tanamanpisang, budidaya tanaman ubikayu dan budidaya tanaman ubi jalar, evaluasi praktek pemasaran hasil produk olahan, pelatihan klasikal: perencanaan pengembangan usaha (business plan) dan pelatihan membangun sistem jaringan kemitraan, Studi Banding (Temu Bisnis) ke Lampung dengan tujuan memperbaiki kualitas produk, variasi produk, variasi kemasan, pengembangan dan membangun kemitraan pemasaran produk hasil olahan dan bahan mentah, permodalan, pelatihan klasikal pemantapan kelompok, Evaluasi dan Sintesa, dan Penyusunan Laporan Penelitian.

Pendampingan akan dilakukan secara terus menerus dari awal sampai penelitian ini berakhir. Sesuai dengan ciri penelitian terapan, luaran penelitian yang merupakan target peneliti adalah model peningkatan pendapatan transmigran melalui penerapan kombinasi strategis teknologi tepat guna terpadu yang langsung dapat dimanfaatkan oleh masyarakat transmigran.

\section{TINJAUAN PUSTAKA}

Undang-undang Nomor 15 Tahun 1997 tetang Pembangunan Ketransmigrasian mengamanatkan bahwa sasaran penyelenggaraan transmigrasi adalah meningkatkan kemampuan dan produktivitas masyarakat transmigran, membangun kemandirian dan mewujudkan integrasi di pemukiman transmigrasi sehingga kondisi ekonomi, sosial dan budaya mampu tumbuh dan berkembang secara berkelanjutan.Pembangunan transmigrasi juga dimaksudkan agar masyarakat dapat mencapai kesejahteraan dalam waktu yang telah 
ditentukan. Pembangunan kawasan transmigrasi dalam kaitannya dengan pembangunan nasional pada hakekatnya bertujuan untuk menyeimbangkan pertumbuhan antar wilayah dan persebaran penduduk, sementara untuk kepentingan daerah bertujuan untuk menciptakan dan membangun pusat-pusat pertumbuhan ekonomi dan meningkatkan kesejahteraan masyarakat di kawasan transmigrasi dan sekitarnya. Terwujudnya pusat pertumbuhan ekonomi baru sangat terkait dengan kegiatan dan peluang ekonomi yang memerlukan partisipasi masyarakat dan dunia usaha/swasta sebagai mitra kerja.Program pembangunan transmigrasi yang diintegrasikan dengan investasi swasta harus semakin ditingkatkan agar lebih berdaya guna dan berhasil guna.

Paradigma pembangunan permukiman transmigrasi harus dilakukan melalui prinsipprinsip pengembangan wilayah (regional development) yang bersifat lestari (sustainable). Untuk mencapai hal tersebut, diperlukan suatu model pengembangan wilayah yang didukung oleh pengembangan masyarakat (community development) yang memadai.Penyelenggaraan transmigrasi diharapkan dapat memperbaiki citra pembangunan daerah dan diterima berbagai pihak khususnya daerah-daerah yang masih membutuhkan kegiatan pengembangan sumberdaya alam dan sumber daya manusia.

Dalam rangka menghadapi tuntutan perkembangan global, memajukan transmigran dan mengembangkan usaha pihak swasta, maka harus diupayakan pembentukan transmigran yang mempunyai motivasi, kemauan tinggi, dan semangat untuk memberdayakan lahan usaha yang ada yang disesuaikan dengan pola usaha yang diusahakan di lokasi tersebut. Program keterpaduan antara pembangunan dan pemberdayaan masyarakat miskin cenderung mengabaikan peranan perempuan (Fortman \& Rocheheleau, 1989; Prasai et al, 1989; ILO, 1989 dalam Soengkono, 2002, 2007, 2009). Terabaikannya pelibatan potensi dan kontribusi perempuan melalui perannya dalam proses pembangunan dan pemberdayaan akan menimbulkan dampak negatif pada program tersebut. Dengan demikian perhatian dan pelibatan perempuan keluarga dalam hubungannya dengan pengelolaan sumberdaya alam perlu mendapatkan pertimbangan.

Pola pembangunan transmigrasi yang diterapkan di lokasi UPT Karang Cahyo adalah Pola TULK (Transmigrasi Umum Lahan Kering) letaknya berbatasan langsung dengan dengan hutan lindung BPT Bukit Rabang (Reg. 78) dan HPT Air Talo (Reg. 77). Karena polanya TULK maka kegiatan usaha diarahkan dan difokuskan pada sektor pertanian-perkebunan. Saat ini belum ada kegiatan-kegiatan usaha ekonomi di luar sektor pertanian yang dilakukan oleh warga transmigran. Padahal banyak potensi yang dapat dikembangkan dan diusahakan dalam usaha meningkatkan ekonomi (pendapatan) keluarga dari komoditas-komoditas pertanian yang mereka hasilkan saat ini seperti pisang, ubi kayu, ubi jalar, dan sayur-mayur. Komoditaskomoditas tersebut di usahakan warga transmigran karena komoditas utama seperti kepala sawit dan karet yang mereka usahakan pada lahan usaha yang bersifat marjinal belum menghasilkan, sehingga untuk mempertahankan kehidupan rumah tangga mereka, warga transmigran menanam tanaman holtikultura tersebut secara tumpang sari.

Permasalahan-permasalahan lain yang dimiliki warga transmigran UPT Karang Cahyo adalah pola usahatani yang umumnya masih menggunakan teknik-teknik tradisional dan masih terbatas. Sementara itu, lahan-lahan yang bersifat marjinal menjadi persoalan tersendiri. Lahanlahan marginal ini dalam pengelolaanya memerlukan input produksi yang relatif tinggidan rawan terhadap terjadinya degradasi. Jika hal ini tidak mendapat perhatian dan penanganan sesegera mungkin, kemungkinan para transmigran akan sulit mencapai taraf kenidupan yang berkecukupan ekonomi keluarganya dan terus terbelenggu pada lingkaran kemiskinan dan kesengsaraan (Praningrum, 2009).

Selain itu, program pembangunan ketransmigrasian di lokasi-lokasi unit permukiman transmigrasi pada umumnya cenderung mengabaikan peranan kaum perempuan dan seringkali mempunyai asumsi keliru, bahwa hanya kaum laki-laki sajalah yang mempunyai pengaruh dominan dalam pembangunanekonomi masyarakat, sehingga dimana setiap kebijakan pembangunan hampir semua sasarannya adalah kaum laki-laki. Terabaikannya potensi dan kontribusi ekonomi perempuan melalui peningkatan perannya dalam proses pembangunan akan menimbulkan dampak negatif pada program pembangunan itu sendiri yang selanjutnya 
dapat mengakibatkan kegagalan program pembangunan ekonomi masyarakat itu sendiri (Soengkono, 2007). Oleh karena itu, keterlibatan perempuan dalam pembangunan unit permukiman transmigrasi perlu mendapatkan perhatian. Rendahnya partisipasi kaum perempuan dalam program pembangunan dan pengembangan UPT ditunjukkan oleh hasil penelitian Suminar (2004) yang mencerminkan bahwa mayoritas program pengembangan masyarakat hanya mempertimbangkan suara kaum laki-laki saja sebagai "suara masyarakat", sehingga sebetulnya yang disebut community awareness adalah men awareness only.

Berdasarkan pada kondisi tersebut, maka sangat diperlukan adanya pola pendekatan persuasive melalui pengembangan usaha perspektif gender, agar peran ekonomi perempuan warga transmigran khususnya dan pengembangan ekonomi warga transmigran umumnya dengan menggunakan berbagai kombinasi strategis melalui penerapan teknologi tepat guna sederhana industri rumah tangga berbasis potensi lokal. Pengembangan peran ekonomi transmigran yang berdimensi pada proses penyadaran (awareness) psikologi masyarakat sebenarnya akan menjadi lebih penting sebagai satu sistem pendukung kehidupan (life-support system) keluarga transmigran itu sendiri (Suminar, 1999). Sementara pendapat Arcury dan Christianson (1998) dalam (Soengkono, 2002) mengatakan bahwa strategi pemberdayaan ekonomi masyarakat melalui pemanfaatan potensi lokal dalam proses diseminasinya dapat dengan mudah diadopsi oleh masyarakat sasaran penelitian.

Dalam pemberdayaan ekonomi masyarakat, diperlukan satu pendekatan baru dengan menganalisis proses aktivitas ekonomi masyarakat dan kelompok masyarakat tersebut terhadap lingkungannya. Pendekatan tersebut harus mampu menggambarkan bukan hanya konsep perilaku aktivitas ekonomi itu sendiri melainkan juga konsep ekosistemyang menjadi media dilakukannya perilaku aktivitas ekonomi.Pendekatan ekosistem memungkinkan peneliti untuk menganalisis hubungan antara manusia dengan lingkungannya lebih terbuka dan dinamis dibanding dengan pendekatan-pendekatan sebelumnya. Pendekatan ekosistem seperti yang ditegaskan Morgan (dalam Soengkono, 2007) akan menghasilkan basis data yang sangat bermanfaat untuk pembuatan model yang terintegrasi. Slocombe (dalam Praningrum, 2009) mengidentifikasi beberapa keuntungan dari diterapkannya pendekatan ekosistem, antara lain (1) pendekatan tersebut sifatnya komprehensif, holistic untuk memahami keseluruhan sistem; (2) mendorong pemikiran preventif melalui penempatan manusia yang disesuaikan dengan alam; (3) memfasilitasi tindakan-tindakan yang sesuai, penumbuhan kepercayaan diri dan berkelanjutan; (4) memfasilitasi kerjasama, mengurangi konflik dan mengintegrasikan kelembagaan; (5) menerapkan teori dan praktek dari berbagai disiplin untuk menghasilkan model dan hipotesis. Melalui pendekatan ini, penelitian ini akan menganalisis perilaku aktivitas ekonomi warga transmigran dalam situasi dan kondisi di lingkungan sekitarnya.

Sebenarnya, perubahan perilaku ekonomi masyarakat dapat direkayasa melalui pemberian penerangan dan pelatihan yang disesuaikan dengan pengetahuan dan kemampuan mereka akan terjadi perubahan pola hidup (Suminar, 2004). Salah satu alternatif model pengembangan ekonomi warga transmigran di unit permukiman transmigrasi (UPT) Karang Cahyo adalah penemuan model teknologi sederhana untuk mengolah komoditas-komoditas pertanian yang masih memilih nilai tambah seperti pisang dan umbi-umbian. Teknologi sederhana artinya adalah teknologi yang mudah diserap dan dilakukan oleh warga transmigran berikut anggota keluarganya dengan biaya relatif murah. Dengan teknologi ini warga transmigran terutama kaum perempuan akan lebih mampu menggunakan waktu luangnya untuk kegiatan ekonomi produktif seperti pengolahan keripik pisang dan keripik ubi kayu/ubi jalar yang memiliki nilai tambah tinggi jika dibandingkan dijual dalam bentuk mentah. Penerapan teknologi sederhana ini memiliki efek pengganda (multiplier effect), yakni terbukanya peluang-peluang usaha lainnya seperti tumbuhkembangnya perdagangan di tingkat lokal.

\section{METODOLOGI}

Penelitian ini akandilakukan dengan menggunakan metode diskriptif kualitatif dan pendekatan Partisipatory Rural Appraisal (PRA), yaitu langsung mengarahkan pada keadaan dan pelakuekonomi masyarakat transmigran tanpa mengurangi unsur-unsur yang ada di 
dalamnya. Dengan menggunakan kombinasi strategis pendekatan ini diharapkan penelitian ini mampu menggali informasi dan permasalahan-permasalahan ekonomi di masyarakat maupun faktor-faktor yang melatarbelakangi kehidupan ekonomi masyarakat transmigran di lokasi penelitian. Sementara itu inovasi teknologi tepat guna terpadu yang diterapkan, sebenarnya adalah pilihan kombinasi teknologi yang relevan dan lebih mendekatkan pada tingkat keberhasilan penelitian, yakni:untuk meningkatkan produktivitas, nilai tambah (addedvalue) danakses pasar pada usaha mikro yang telah dijalankan oleh masyarakat transmigran dalam upaya mengatasi tekanan ekonomi masyarakat transmigran. Makna dan konsep yang digunakan dalam kajian ini dapat pula tertangkap dengan menggunakan metode kualitatif (Bogdan dan Taylor, 1995).Penelitian ini merupakan kaji tindak (action research) dan ekplorasi yang bertujuan untuk mengembangkan pengetahuan bidang manajemen usaha mikro yang mendalam mengenai obyek penelitian.

\section{HASIL PENELITIAN}

\section{Hasil Temuan Lapangan}

a) Permasalahan bantuan mesin pengolah aneka keripik dan keripik buah (Vacum Frierer/Frieying) dari Kementerian Transmigrasi dan Tenaga Kerja. Permasalahan adalah:

- Energinya menggunakan energi listrik, sementara di UPT Karang Cahyo tidak ada aliran listrik (PLN).

- Mesin berkapasitas besar (baca: kapasitas produksi besar dan biaya operasi besar), kondisi ini tidak sesuai dengan kemampuan ekonomidan ketrampilan/keahlian warga masyarakat transmigran.

- Tidak ada pelatihan mengenai penggunaan dan pemeliharaan mesin.

- Bantuan mesin dari tahun 2009 sampai sampai saat ini 2012 mesin tersebut belum dimanfaatkan.

b) Permasalahan Harga Jual karet rakyat sebagai mata pencaharian pokok masyarakat transmigran. Permasalahan adalah:

- Masyarakat tidak mampu akses pasar, seperti ke pabrik-pabrik karet yang banyak terdapat di Provinsi Bengkulu, sehingga sampai saat penelitian ini dilakukan masyarakat masih ada ketergantungan pada tengkulak, akibatnya adalah adanya tekanan harga dan dimungkinkan perlakuan sistim ijon.

- Harga jual karet sangat rendah, yaitu sebesar Rp. 7.000,-/kg. Sementara harga pabrik sampai Rp. 18.000,- sampai Rp. 20.000,- karet kering.

- Pengambilan karet waktu tidak pasti, sehingga karet menjadi kering dengan harga beli yang sama. Hal ini merupakan kerugian bagi masyarakat transmigran.

c) Fenomena politik praktis yang terjadi di kalangan masyarakat transmigran seperti pemilihan kepala desa yang berdampak pada kinerja KUB. Permasalahannya adalah:

- Hubungan kemasyarakatan antar warga transmigran terjadi ketegangan, terutama antara pendukung calon satu dengan calon lainnya, sehingga mempengaruhi hubungan kerjasama antar warga transmigran sendiri.

- Fanatisme dan loyalitas terhadap salah satu calon kepala desa, membuat dinamika politik berujung pada ketidak-kompakan warga transmigran dan mudah diprovokasi.

\section{Hasil Kaji Tindak}

Untuk melakukan penguatan ekonomi warga transmigran yang masih relatif 'memprihatinkan' pemberdayaan dan pendampingan masyarakat perlu dilakukan, terutama berkaitan dengan penciptaan nilai tambah atas komoditas-komoditas pertanian yang masih belum termanfaatkan seperti pisang dan ketela pohon. Proses penciptaan nilai tambah tersebut melalui sentuhan-sentuhan teknologi pengolahan sederhana yang mudah diadopsi dan murah. Walaupun bersifat usaha sampingan, diharapkan nantinya usaha tersebut dapat memberikan kontribusi yang besar terhadap peningkatan ekonomi dan kesejahteraan warga transmigran sendiri. 
Berkaitan dengan proses penciptaan nilai tambah (addedvalue) tersebut, warga transmigran didinamisasi dan diberi pelatihan-pelatihan penggunaan teknologi dan sekaligus pelatihan manajemen usaha kecil (MUK) untuk pengembangan usaha agar wawasan dan jiwa wirausaha warga transmigran dapat tumbuh dan berkembang serta meningkatkan kreativitas dalam usahanya.

Dalam proses mendinamisasi untuk membangun warga masyarakat transmigran (Community Development) tersebut ada beberapa tahapan yang dilakukan oleh peneliti, yakni sebagai berikut:

\section{Tahap Orientasi, Adaptasi dan Sasaran Penelitian}

Berdasarkan pada maksud, tujuan dan pendekatan penelitian (baca: Kaji Tindak dan PRA), maka dalam tahap awal kunjungan penelitian ini dilakukan orientasi dan adaptasi terhadap komunitas sasaran penelitian. Dalam tahap ini penentuan target atau sasaran kaji tindak akan dilakukan berdasarkan minat masyarakat warga transmigran yang benar-benar mau mengikuti program dalam mencari upaya-upaya meningkatkan ekonomi keluarga melalui usaha-usaha mikro alternatif berbasis dengan Ekonomi Sumberdaya Alam, Ekonomi Sumberdaya Manusia dan Dukungan Lingkungan Usaha. Hal ini dilakukan bertujuan agar dalam pelaksanaan kegiatan penelitian akan benarbenar dapat diterima (baca: tidak ada unsur paksaan) dan dapat diikuti secara sungguhsungguh oleh sasaran penelitian.

\section{Tahap Sosialisasi Program}

Dalam penelitian sosialisasi program adalah penting dan merupakan kunci keberhasilan penelitian, karena tahap ini akan menentukan kegiatan penelitian tersebut diterima atau ditolak oleh komunitas penelitian. Selain itu sosialisasi program juga memiliki tujuan agar terjadi kesatuan visi dan misi antara peneliti dan masyarakat sasaran penelitian, sehingga diharapkan pada proses pelaksanaan tindakan berjalan tidak akan ditemukan permasalahan atau kendala yang seharusnya tidak perlu terjadi.

Pada kegiatan sosialisai program agar ini tim peneliti menggunakan pendekatan Focus Group Discussion (FGD) dan Indept Interview dengan masyarakatwarga transmigrasi UPT Karang Cahyo sebagai komunitas sasaran kegiatan penelitian. Teknik ini digunakan agar kedekatan antara tim peneliti dan komunitas sasaran penelitian berjalan dengan baik dan data primer yang diperoleh berdimensi "grass-roots" data. Selain itu peserta diskusi, tim peneliti juga melibatkan tokoh masyarakat, ketua adat, aparat desa formal dan non formal. Hal ini dilakukan agar proses penelitian memperoleh pemahaman yang menyeluruh dan tuntas, terkait dengan maksud dan tujuan penelitian dilakukan.

\section{Identifikasi, Permasalahan dan Need Assesment}

Hasil identifikasi menunjukkan bahwa pola perilaku kegiatan ekonomi masyarakat transmigran sangat tergantung dengan kondisi alamnya yang relatif kurang subur. Sedangkan pola usaha yang dikembangkan belum berorientasi pada bisnis (non profit oriented) dan hanya sekedar untuk pemenuhan kebutuhan hidup sesaat dan bukan berupaya bagaimana usahanya dapat dikelola secara produktif (profit oriented) dan berkelanjutan. Selain itu kurangnya in-put teknologi, dana untuk biaya operasi dan pembinaan yang bekelanjutan membuat masyasrakat transmigran mengalami kesulitan untuk mengembangkan usahanya.

Hasil identifikasi kebutuhan (needassesment) untuk pengembangan ekonomi masyarakat transmigran UPT Karang Cahyo Kecamatan Pino Raya Kabupaten Bengkulu Selatan, teridentifikasi beberapa permasalahan:

1. Masyarakat transmigran sebenarnya memiliki motivasi yang tinggi untuk tetap tinggal di lokasi transmigrasi dan melaksanakan kegiatan usaha ekonomi pertanian untuk meningkatkan pemenuhan kebutuhan hidup keluarganya. 
2. Masyarakat transmigran sulit mengembangkan perekonomian karena tanaman pokok yang ditanam pada lahan pekarangan dan lahan usaha belum menghasilkan secara optimal.

3. Masyarakat transmigran mengaku bahwa tanaman pokok (kakao, kelapa sawit dan karet) yang mereka tanam kurang berkualitas sehingga sampai dengan saat penelitian ini dilakukan tanaman tersebutbelum menghasilkan sesuai dengan harapan.

4. Masyarakat transmigran dalam mensiasati untuk memenuhi kebutuhan keluarga menanam tanaman palawija dan bekerja secara serabutan, baik sebagai buruh tani maupun kuli bangunan di luar UPT Karang Cahyo.

5. Masyarakat transmigran memiliki keterbatasan kualitas sumber daya manusia sehingga tidak memiliki keahlian, pengetahuan, dan daya saing yang relatif rendah.

6. Banyaknya potensi sumber daya lokal terutama pada komoditas pisang, ketela pohon dan ubi jalar yang belum teroptimalkan produktivitasnya (masyarakat biasa menjualnya dalam bentuk mentah pada tengkulak yang datang ke lokasi transmigrasi dengan harga murah), padahal sebenarnya produk-produk tersebut masih memiliki nilai tambah yang dapat meningkatkan pendapatan warga transmigran.

7. Masyarakat transmigran memohon agar difasilitasi dalam kegiatan pengembangan usaha ekonominya terkait dengan pengelolaan tanaman pangan yang saat ini dikelolanya seperti dalam bentuk pengolahan pisang, ubi kayu, dan ubi jalar.

8. Di lokasi UPT sudah ada bantuan mesin "Vacum Friying" dari Kementerian Transmigrasi, namun sampai saat ini belum dapat dimanfaatkan, karena beberapa alasan seperti : input produksi yang tinggi, energi penggerak mesin menggunakan tenaga listrik berkapasitas besar, kurangnya pengetahuan warga dalam mengoperasikan mesin, tidak ada pelatihan teknis, dan berbagai keterbatasan teknis lainnya.

\section{Tahap Pembentukan Kelompok Usaha Bersama (KUB)}

Kelompok merupakan suatu wadah untuk memudahkan proses dinamisasi masyarakat sasaran kegiatan agar mencapai tujuan yang ingin dicapai. Beberapa tahapan kegiatan dalam tahap pembentukan kelompok usaha bersama (KUB) adalah sebagai berikut:

- Sosialisasi program kepada warga transmigran mengenai pembentukan Kelompok Usaha Bersama (KUB) yang dapat menjadi wadah peningkatan ekonomi bersama anggota.

- Musyawarah warga transmigran dalam penentuan perlunya pembentukan KUB untuk mendukung kegiatan ekonomi keluarga.

- Musyawarah warga transmigran untuk menentukan maksud dan tujuan, nama, pengurus, aturan main, kegiatan usaha dan kedudukan KUB yang dibentuk di lokasi penelitian.

- Sosialisasi keberadaan KUB dan pendaftaran anggota oleh para pengurus di lokasi penelitian.

Berdasarkan hasil kesepakatan dengan masyarakat transmigrasi UPT Karang Cahyo Kecamatan Pino Raya Kabupaten Bengkulu Selatan dibentuk dengan nama "SARI MAKMUR" dengan susunan pengurus KUB sebagai berikut: 
Gambar 1. Struktur Organisasi Kelompok Usaha Bersama (KUB) Sari Makmur

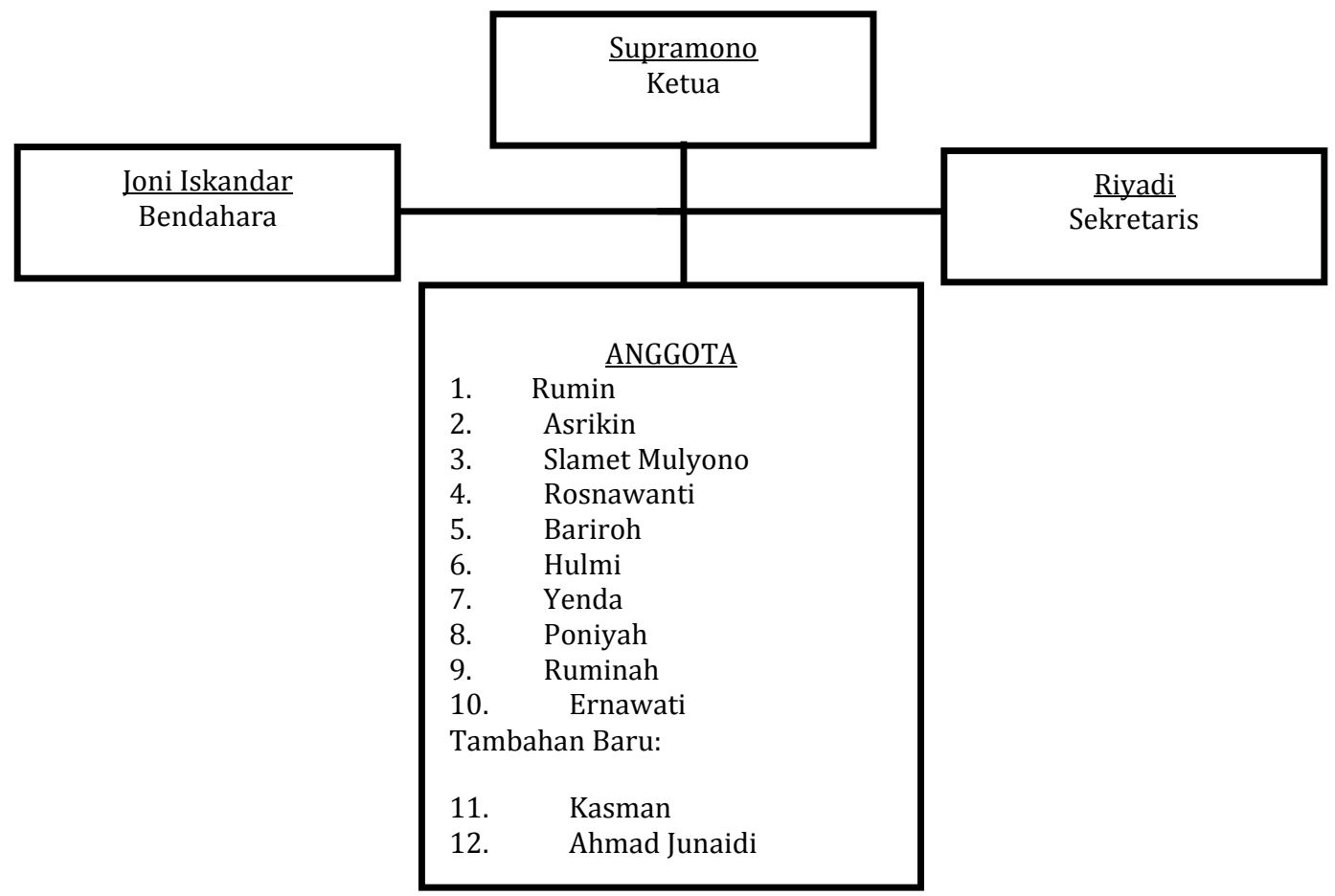

\section{Tahap Pelaksanaan Tindakan}

a) Pelaksanaan Pelatihan Klasikal Manajemen Usaha Kecil

- Musyawarah anggota KUB dalam perencanaan kegiatan usaha yang akan dilakukan jangka pendek

- Musyawarah anggota KUB mengenai prioritas usaha yang dilakukan, hak dan kewajiban pengurus dan anggota serta mekanisme (tata kerja) pelaksanaan kegiatan.

- Musyawarah anggota KUB untuk menentukan kebutuhan utama (need assesment) anggota yang dapat diusahakan KUB kaitannya dengan peningkatan ekonomi warga transmigran.

- Musyawarah anggota KUB mengenai permodalan awal dan sumber-sumber modal usaha KUB

b) Pelaksanaan Praktik Ujicoba Kombinasi Teknologi Pengolahan

Pelaksanaan praktik ujicoba kombinasi teknologi pengolahan yang dilakukan meliputi:

1) Teknologi pengolahan keripik pisang dan keripik ketela pohon aneka rasa (tawar, manis, asin, barbeque, coklat dan keju).

2) Teknologi Sablon dan Kemasan

c) Pendampingan dan Praktik Pemasaran Produk Hasil Olahan

Pelaksanaan pendampingan dilakukan peneliti dalam kegiatan usaha pemasaran produk hasil olahan, termasuk strategi-strategi promosi produk dan inovasi produk hasil olahan.

\section{Pendampingan dan Fasilitasi Pengembangan Usaha KUB}

\section{a) Pendampingan dalam Penataan Organisasi KUB}

Pendampingan dalam penataan organisasi KUB dilakukan untuk mengatur kepengurusan dan administrasi yang berorientasi pada usaha. Aspek-aspek yang difasilitasi adalah :

1) Memperkokoh kepengurusan

2) Pembangkitan partisipasi anggota 
3) Peningkatan pengetahuan dan pemahanan tentang kegiatan usaha

4) Pembagian tugas dan wewenang

5) Pengembangan Usaha

6) Membangun system Kemitraan

b) Pelatihan Pengembangan Usaha

1. Pelatihan manajemen usaha kecil dan manajemen produksi (lanjutan)

2. Fasilitasi sistem administrasi dan pembukuan

3. Pendampingan cara pemasaran

\section{Indikator Keberhasilan}

Dari kegiatan dinamisasi dan pemberdayaan ekonomi masyarakat warga transmigran UPT Karang Cahyo, beberapa indikator keberhasilan yang dapat diperoleh adalah :

1. Terciptanya sebuah kelembagaan KUB yang implementatif untuk menumbuhkembangkan jiwa wira usaha masyarakat warga transmigran sebagai motor penggerak perekonomian warga transmigran.

2. Berkembangnya kegiatan ekonomi masyarakat melalui KUB yang mampu mengembangkan partisipasi dan kesadaran masyarakat untuk lebih giat berusaha memanfaatkan potensi lokal secara maksimal.

3. Bertambahnya jumlah anggota baru yang berminat untuk masuk menjadi anggota Kelompok Usaha Bersama (KUB).

4. Terwujudnya model kelembagaan KUB sebagai salah satu alternatif strategi pemberdayaan masyarakat untuk ketahanan pangan.

5. Terciptanya produk hasil olahan yang memiliki nilai tambah

6. Terciptanya produk hasil olahan yang memiliki nilai jual

7. Terjualnya hasil produk olahan di pasaran pada tingkat lokal

8. Pendapatan anggota KUB meningkat.

9. Terciptanya sebuah model Pemberdayaan Ekonomi Masyarakat Transmigran, berbasis potensi lokal (ESDA, ESDM dan Lingkungan Bisnis).

\section{SIMPULAN}

Berdasarkan hasil penelitian yang telah dilakukan di kawasan UPT Karang Cahyo, Desa Karang Cahyo, Kecamatan Pino Raya Kabupaten Bengkulu Selatan dapat disimpulkan sebagai berikut.

1. Kondisi lahan dengan tingkat kesuburan tanahnya yang relatif rendah menyebabkan volume hasil produksi tanaman pokok seperti: kelapa sawit, karet dan palawija relatif rendah. Lemahnya akses pasar dan kendala transportasi, masyarakat transmigran dalam menjual hasil panen tanaman pokok sangat tergantung dan dikendalikan oleh para tengkulak, sehingga harga jual yang diterima masyarakat transmigran sangat rendah. Berdasarkan kondisi tersebut di atas, maka pemanfatan lahan termasuk pekarangan rumah belum dimanfaatkan secara optimal dan terlihat banyak lahan terlantar yang ditumbuhi semak belukar.

2. Tanaman sampingan seperti: pisang, ubi kayu, ubi jalar, papaya, nangka, cabe, mangga dan hasil tanaman sampingan lainnya. Penanganan pasca panen dengan produk yang memiliki sifat ketahanan kualitas produk, yakni waktu simpan yang sangat terbatas, mudah rusak dan tidak adanya in-put teknologi para transmigran menjual produk masih dalam bentuk mentah (baca: petik-jual). Akibatnya adalah ketergantungan dengan para tengkulak sangat tinggi, sehingga harga jual dipermainkan dan ditekan serendah mungkin oleh tengkulak.

3. Kualitas sumberdaya manusia relatif cukup, namun dengan kurangnya pembinaan dan pendampingan secara berkelanjutan mengakibatkan potensi sumberdaya manusia tersebut tidak dapat termanfaatan secara optimal. Penerapan teknologi tepat guna terpadu (pengolahan, sablon, kemasan dan Manajemen Usaha Kecil (MUK) melalui pelatihan dan praktik uji coba, khususnya ditujukan pada tanaman sampingan seperti: pisang, ubi kayu dan ubi jalar pada usaha mikro agar lebih produktif, memiliki nilai tambah dan akses pasar, 
masyarakat transmigran mampu meningkatkan pendapatan keluarga dan kehidupan warga transmigran dirasakan menjadi lebih baik.

4. Bentukan Kelompok Usaha Bersama (KUB) dapat berjalan sesuai dengan peran dan fungsinya sebagai penggerak ekonomi masyarakat transmigran di UPT Karang Cahyo, baik sebagai penampung/pengumpul, pengolah maupun pemasaran hasil pasca panen tanaman sampingan. Sementara itu data terakhir menunjukkan bahwa jumlah anggota KUB semakin bertambah banyak. Oleh karena itu ke depan diharapkan KUB ini dapat berkembang dan pada saatnya nanti dapat menjadi Koperasi Usaha Tani yang Mandiri karena keberadaannya berbasis pada kebutuhan dan keinginan masyarakat transmigran itu sendiri.

5. Kelompok Usaha Bersama (KUB) sebenarnya sebagaimana peran dan fungsinya memiliki dampak ganda (Multiplier Effect), seperti pemberdayaan ekonomi perempuan transmigran, penyerapan tenaga kerja dan memiliki kekuatan tawar (bargaining power) yang sangat diperlukan dalam menghadapi tekanan para tengkulak dan sistem ijon.

6. Pelaksanaan pelatihan-pelatihan dapat berjalan sesuai dengan rencana, tahapan-tahapan dan tujuan pelatihan, meliputi: pelatihan Manajemen Usaha Kecil (manajemen operasi, manajemen sumberdaya manusia, manajemen keuangan, manajemen pemasaran dan analisa lingkungan bisnis). Selain itu juga ada pelatihan khusus Manajemen Pemasaran Produk Hasil Olahan.

7. Praktik Uji-coba dapat berjalan sesuai dengan rencana dan tahapan-tahapan dalam pelaksanaan, meliputi: Praktik Uji-coba pengolahan kripik pisang, ubi kayu, ubi jalar dengan berbagai variasi bentuk dan rasa, usaha sablon dan usaha kemasan dengan tampilan berbagai warna dan ukuran.

8. Pendampingan dan Pemasaran produk hasil olahan telah dipraktikkan pada pasar tingkat lokal (Kabupaten) dan hasilnya cukup berarti dalam membantu meningkatkan pendapatan rumah tangga anggota KUB.

9. Pelatihan Lanjutan Pengembangan Usaha (business plan) telah dilakukan dan ada beberapan kesepakatan anggota dalam perencanan untuk pengembangan usaha ke depan, meliputi: pengembangan tanaman sebagai bahan mentah, penjualan produk jadi dan bahan mentah, membangun jaringan kemitraan dengan sistim titip-laku-bayar/titip-bulan-bayar ke tokotoko penjual makanan, rumah-rumah makan dan agen-agen bus dan agen travel.

\section{REKOMENDASI}

Hasil kaji tindak inovasi teknologi tepat guna untuk meningkatkan produktivitas, nilai tambah dan akses pasar usaha mikro di UPT Karang Cahyo dilaksanakan pada tahap tahun pertama sudah dilakukan. Selanjutnya agar model pemberdayaan ekonomi dalam upaya pengentasan kemiskinan melalui kelembagaan Kelompok Usaha Bersama (KUB) lebih berdaya guna dan tuntas. Berdasarkan hasil kajian dan temuan di lapangan, maka ada beberapa rekomendasi yang perlu mendapatkan perhatian antara lain:

1. Kemantapan dan Kemandirian Kelompok Usaha Bersama (KUB) agar dapat berkembang dan lebih berdaya guna perlu terus ditingkatkan. Tujuannya adalah agar keberadaan KUB benar-benar sebagai wadah kegiatan ekonomi dan motor penggerak perekonomian di UPT Karang Cahyo berbasis pada peluang-peluang ekonomi lokal yang dapat dikembangkan untuk usaha-usaha KUB yang berkelanjutan (sustainable).

2. Pemanfatan lahan terlantar dan pekarangan rumah perlu diberdayaan untuk tanaman pisang, ubi kayu dan ubi jalar sebagai bahan baku pada usaha yang telah dilakukan sekarang dalam mempertahankan dan mengembangkan keberlanjutan usaha-usaha KUB. Diharapkan KUB tidak hanya memproduksi produk hasil olahan, tetapi juga dapat sebagai pemasok bahan mentah di sentra-sentra industri pengolahan hasil pertanian secara regional maupun nasional.

3. Pengembangan Sistim Kemitraan perlu terus diupayakan seperti kerjasama dengan tokotoko penjual makana dan agen-agen bus dan travel dengan sistim titip-bayar atau titip-bulabayar.

4. Berkaitan dengan rekomendasi ni 1,2 dan 3 dan sesuai dengan tahapan penelitian tahun ke 2, tahapan Studi Banding ke daerah sentra industri seperti Lampung menjadi sangat penting 
untuk dilakukan dalam upaya membuka wawasan dan pengembangan bisnis. Selain itu diharapkan dalam Studi Banding ini KUB juga dapat belajar bagaimana mengoperasikan dan memelihara mesin vacum frierer/frieyingbantuan dari Kementerian Transmigrasi dan Tenaga Kerja yang sejak tahun 2009 sampai penelitian ini dilakukan tidak termanfaatkan.

5. KUB untuk lebih berdaya guna dapat memfasilitasi penjualan hasil perkebunan karet rakyat ke pabrik-pabrik pengolah karet yang banyak terdapat di Provinsi Bengkulu, sehingga pendapatan meningkat karena harga yang diperoleh warga transmigran memadai (harga pabrik) dan lepas dari keterhantungan pada tengkulak.

\section{DAFTAR PUSTAKA}

Achmad, R, 1992, Pola Belajar Kewiraswastaan Petani Miskin: Studi Kasus Di Desa MangenJawa Tengah, Jurnal Penelitian IKIP Semarang, No. 3 Tahun VIII.

Azehari, S , 1991, Analisis Situasi Wanita Di Propinsi Bengkulu. Bengkulu: Pemda Tk I dan PSW UNIB

Badan Pusat Statistik Bengkulu, 2004, Bengkulu Dalam Angka. Bengkulu: BPS Bengkulu

Biro Pusat Statistik, 2001, Analisis Situasi Wanita Dalam Pembangunan Di Kabupaten Bengkulu Utara. Bengkulu: Pemda Tingkat I dan PSW UNIB

Bogdan, Robert dan Steven J. Taylor, 1995, Introduction To Qualitative Research Method. New York: John Willey Sons

Chambers, Robert dan Steven J. Taylor, 1992, Rurak Appraisal: Rapid, Relaxed and Participatory. English: Institute of Development Studies

Dinas Tenaga Kerja dan Transmigrasi Provinsi Bengkulu, 2006. Laporan Akhir Rencana Teknis Satuan Permukiman (RTSP) UPT Karang Cahyo Kecamatan Pino Raya Kabupaten Bengkulu Selatan, Bengkulu

Dinas Tenaga Kerja dan Transmigrasi Provinsi Bengkulu, 2009. Laporan Akhir Rencana Teknis Pembinaan (Rentekbin) UPT Karang Cahyo Kecamatan Pino Raya Kabupaten Bengkulu Selatan, Bengkulu

Fitiyah, 1990, Hubungan Stutus Sosial Ekonomi Petani Miskin Dengan Alokasi Curahan Kerja Wanita Pada Rumah Tangga Petani di Gunung Kidul Wonogiri,Surakarta : Lembaga Penelitian Universitas 11 Maret

Friedrich-Ebert-Stiftung, 1996, Panduan Praktis Membina Pengusaha Kecil. Jakarta: WISOProject Promotion of Selfhelp-Activities

Kadir, M. S, 1997, "Penelitian Tindakan Untuk Pendidikan", dalam Forum Penelitian Kependidikan: Jurnal Teori Dan Praktik Penelitian Kependidikan IKIP Malang, Tahun 9 Desember, hal. 50-68

Soengkono, 2002, Model Pengembangan Ekonomi Produktif Berbasis Potensi Lokal Masyarakat Di Desa-desa Penyanga Taman Nasional Kerinci Seblat (TNKS) Kabupaten Rejang Lebong Propinsi Bengkulu. Kerjasama KEHATI Jakarta dengan Pusat Penelitian Lingkungan Lembaga Penelitian Universitas Bengkulu 
Soengkono, 2007, Persepsi Perempuan Terhadap Konservasi Dan Pelestarian Taman Nasional Kerinci Seblat. Di Kabupaten Bengkulu Utara: Jurnal Penelitian Universitas Muhammadiyah Bengkulu, Edisi ke 14 No. 2 , Bulan Juni 2005, hlm.206-214

Soengkono, 2009, Perilaku Adaptif Perambah Dalam Hubungannya Dengan Pembangunan Hutan Kemasyarakatan: Studi Kasus Di Hutan Lindung “Bukit Daun” Di Kabupaten Kepahiang Propinsi Bengkulu. Jurnal Penelitian Lembaga Penelitian UNIB

Suminar, 1999.Stratifikasi Gender dan Status Wanita Dalam Keluarga Suku Rejang Di Propinsi Bengkulu.Lembaga Penelitian Universitas Bengkulu

Suminar, 2001, Model Komunikasi, Informasi, dan Promosi (KIP) Konservasi dan Pelestarian Berbasis Pengetahuan Lokal Di Desa-dsa Sekitar Taman Nasional Kerinci Sebblat (TNKS) Di Kabupaten Rejang Lebong Propinsi Bengkulu. Kerjasama KEHATI Jakarta denganLembaga Penelitian Universitas Bengkulu

Undang-Undang Nomor 15 Tahun 1997 tentang Pembangunan Ketransmigrasian, LAN-RI, Jakarta 